\title{
The Effect of Customer's Orientation of Service Employee on Customer's Satisfaction of Health Services
}

\author{
Submitted 02/12/18, 1st revision 27/01/19, 2nd revision 14/03/19, accepted 15/04/19
}

\author{
Sri Isfantin Puji Lestari ${ }^{1}$, Retnoning Ambarwati ${ }^{2}$, Titien Agustina ${ }^{3}$, \\ Endang Muryani ${ }^{4}$, Andriani Andriani ${ }^{5}$, Muhammad Alfani ${ }^{6}$
}

\begin{abstract}
:
Purpose: The purpose of this study is to analyze the influence of customer's orientation of service employee (COSE) on customer satisfaction as well as its impact on the customer loyalty in C type of private hospitals in Surakarta, Central Java.

Design/Methodology/Approach: The study uses three variables, namely customer's orientation of service employee (COSE), customer's satisfaction, and customer loyalty. This research uses Structural Equation Modeling (SEM) as research method, and data analysis technique using AMOS 23.0.

Findings: The result of the study shows that COSE had influenced the customer's satisfaction and the customer's loyalty. In conclusion, the customer's satisfaction is an intervening variable that can mediate the effect of variable COSE on the customer's loyalty.

Practical Implications: COSE is something important to affect the performance of the resulting service which will provide customer's satisfaction that will affect customer's loyalty and improve the higher sustainable interaction between service providers (hospital) and patients.

Originality/Value: This is part of a research on the effect of COSE on customer's satisfaction on health services, especially for private hospitals in Indonesia.
\end{abstract}

Keywords: COSE, satisfaction, loyalty, health service.

JEL Code: M31, M37.

Paper Type: Research article.

${ }^{1}$ STIE Wijaya Mulya Surakarta, Jl. Kutai Raya, Sumber, Banjarsari, Kota Surakarta, Jawa Tengah 57138, Indonesia, email: siplestari.stiewijayamulya@gmail.com

${ }^{2}$ STIE Wijaya Mulya Surakarta, Jl. Kutai Raya, Sumber, Banjarsari, Kota Surakarta, Jawa Tengah 57138, Indonesia.

${ }^{3}$ STIMI Banjarmasin, Jl. Kuripan No.26, Kuripan, Kota Banjarmasin, Kalimantan Selatan 70236, Indonesia.

${ }^{4}$ Universitas Merdeka Surabaya, Jl. Ketintang Madya VII No.2, Karah, Jambangan, Kota SBY, Jawa Timur 60232, Indonesia.

${ }^{5}$ IAIN Kediri, Jl. Sunan Ampel No.7, Ngronggo, Rejomulyo, Kediri, Jawa Timur 64127, Indonesia.

${ }^{6}$ UNISKA MAB Banjarmasin, Jl. Adhyaksa, Sungai Miai, Banjarmasin Utara, Kota Banjarmasin, Kalimantan Selatan 70123, Indonesia. 


\section{Introduction}

Hospital is a public facility that is very important for public health. Health is a primary right for humans since it becomes the determinant factor of other human activities. Progress of hospital concept and technology plays a role in the process of service to the patient. The issue concerning quality development, productivity, and even distribution of services are important points for the hospital sector (Trinastoro, 2005). Hospital preparedness in providing health services is demanded as changes occur. Furthermore, the prominent features are the competitive nature that is the basis for the development of hospital service quality, Without the competitive nature of hospitals in Indonesia it will be difficult to compete with foreign services. Output from hospitals is a product of health care services, so the main principle that must be held in marketing healthcare products is to build and maintain customer trust (patient). In the midst of intense hospital competition, it is important for hospital management to be more professional in managing the hospital in order to survive and develop. Hence, hospital needs to know the satisfaction of the patient.

Kotler (2003) defined satisfaction as a person's feelings of pleasure or dissappointment resulting from comparing a product's perceived performance (or outcome) in relation to his or her expectations. In hospital services, a patient is said to be satisfied if the service performance matches or exceeds the patient's expectation. Hu et al. (2009, p. 115-116) stated that if the performance matches or exceeds the expectations, then the customer is satisfied, if performance is below the customer is dissatisfied. Quality services manifested by service performance are determined by the service delivery behavior of doctors, nurses, medical personnel and administration. This is because the behavior of service delivery plays an important role in shaping the patient's perceptions of service (Andaleeb, 2001).

In the context of hospital services, service delivery person is the last person to carry out hospital marketing efforts and the first person to directly interact with customers. In other words, employees are required to have an orientation on customer needs or customer orientation of service employee (COSE) (Kelley, 1992). According to Thurau and Thorsten (2003) COSE is defined as the behavior of service employees when serving the needs and wishes of existing and prospect customers. Loyalty, in this case the patient, is not formed in a short time but rather requires the learning process from his own experience to the consistent service of employees in the hospital. If the consumer, the patient, gets the service in accordance with what is expected by the patient then the consumer is satisfied. Hence, the behavior of employees as a manifestation of COSE is something that is important to affect the performance of the resulting service which will provide customer satisfaction. The interaction between service providers (hospital) and patients is sustainable which means it will not only ends after the hospitalization treatment is completed, but it will be continued at the time of the patient's re-control in the outpatient poly and at the time of the patient's subsequent examination and treatment. This is because the patient's medical record data placed in the hospital becomes a guide and referral 
examination and treatment so that the treatment of patients can take place comprehensively.

\section{Theoretical Review and Hypotheses}

\subsection{COSE (Customer Orientation of Service Employees)}

Customer orientation refers to understanding and fulfillment according to customer needs during service delivery, while service orientation is a framework which includes sales pitch services and service assistance provided to customers after service is provided (Popli and Rizvi, 2015). The responsibility of employees in providing services to customers is an important key to the success of the company (Ahearne et al., 2005; Brady and Conin, 2001). Customer-oriented service attitudes can help to understand the customer perspectives that ultimately affect the company's profits as far as they fit customer needs (Colwell et al., 2009). Therefore, Thurau and Thorsten (2003) state that Customer Orientation of Service Employee (COSE) is as employee behavior in providing services to customers according to customer needs and desires.

Wong and Sohal (2003) state that the attitude or behavior of employees at each company in providing services, will establish the quality of relationship assessed by customers. For example, it includes: anticipating and understanding customer needs, maintaining customers, delivering on time service, and trying to understand customers with their social skills. Motivation is also needed in the transformation of employees to improve their technical and social skills while providing customeroriented services. Therefore the research hypotheses to cover this are:

H1: The higher the customer orientation of service employees (COSE), the higher the customer satisfaction.

H2: The higher the customer orientation of service employees (COSE), the higher the customer loyalty.

\subsection{The Customer Satisfaction}

Customer satisfaction is important because of customer behavior intentions and customer retention (Roy Dholakia and Zhao, 2010; Cronin et al., 2000; Wilson et al., 2012). There are three aspects in customer satisfaction that have to be considered. The acceptance value, the acceptance quality, and the customer expectation (Jayawardhena and Farrell, 2011). According to Olsen (2002) satisfaction is a function of perceiving performance and expectation. The customers expectation arise because of the needs they want to fulfill, such as customer expectations in obtaining convenient health services from the hospital as long as the customer is undergoing treatment. The alertness of hospitals in handling customer problems (patients) especially during emergency conditions will give a positive impression to customers. In the context of hospital service, the patient satisfaction indicators are as follows: (a) 
very satisfied while in the hospital; (b) happy with the services offered by the hospital; (c) the hospital exceeds the expectations of the patient. Therefore, the research hypothesis can be stated as:

H3 : The higher the customer satisfaction, the higher the loyalty.

\subsection{The Customer Loyalty}

The costumers' loyalty refers to the loyalty to companies that provide goods or services. Meanwhile, customer satisfaction is a factor that determines the level of consumer loyalty. Consumer loyalty is the ideal situation most expected by marketers, where consumers are positive to the product or producer and accompanied by consistent repurchase patterns (Dick and Basu, 1994).

Loyalty can be summed up as a commitment of customers because it gets a satisfaction from the buyer that is reflected by repeated purchases (Jarvis and Wilcox, 1977; Bowen and Chen, 2001). Customer loyalty and willingness to buy a product continuously from the same retailer can occur if the consumer is satisfied with the company's performance. The creation of customer power can provide benefits among others, the relationship between the company and the customer becomes harmonious, providing a good foundation for repeat purchase and the creation of customer loyalty and will make a word of mouth recommendation that benefits the company. There are five factors that cause loyal customers to the brand: a) the brand value; b) the customer characteristics; c) the switching barrier; d) the consumer satisfaction; d) the competitive environment.

Based on the literature review, we propose a research model that shows the influence of COSE on customer satisfaction and its impact on loyalty. Figure 1 is a proposed model of building the variables that affect customer loyalty.

Figure 1: Variables model affecting employee performance

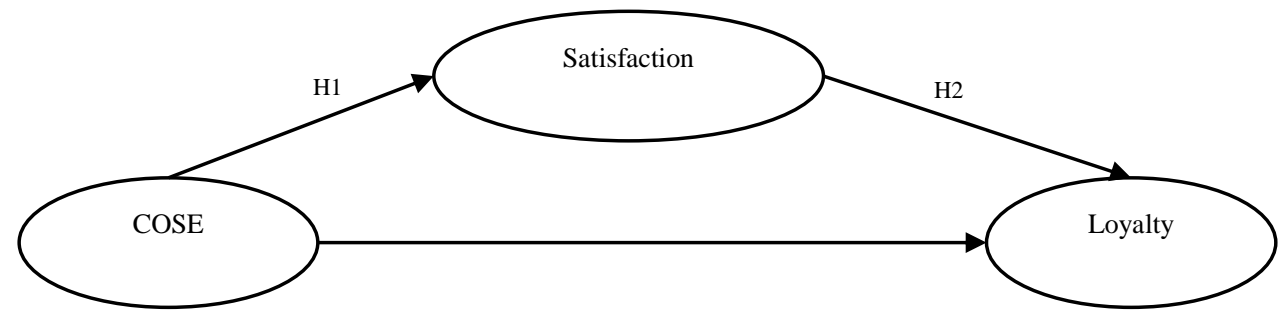

Based on the background, problem formulation, literature review and conceptual framework built, the following hypotheses are proposed: 
H1. The costumer orientation of service employee (COSE) has a significant and positive effect on customer satisfaction (CS).

H2. Costumer orientation of service employee (COSE) has a significant and positive effect on customer loyalty.

H3. Costumer orientation of service employee (COSE) has a significant and positive effect on customer loyalty through customer satisfaction (CS).

\section{Research Methodology}

The study uses three variables, namely customer orientation of service employees (COSE), customer satisfaction, and customer loyalty. This explanatory research is explaining or clarifying an event or relationship such as testing the influence of some variables. Therefore, the research uses Structural Equation Modeling (SEM) as the appropriate research method, and data analysis technique using AMOS 23.0. The population of the study includes outpatients who have undergone inpatient in private hospitals such as Panti Waluyo Hospital, Brayat Minulyo Hospital, and Kustati Hospital since 2017. The sampling technique used in this research is simple random sampling. The sample were outpatients who used BPJS services over the age of 17 years. On average there were 785 patients every month. Sample size according to SEM based on the study by Ferdinand (2000) is equal to about 100-200 units. In this study we have used 200 patients as our sample.

\section{Results}

The evaluation of good suitability on structural equation model after modification in accordance with modification indices is presented in Table 1.

Table 1. Results of the Goodness of Fit Indices Model Modification

\begin{tabular}{|c|c|c|c|}
\hline Index fit & Result & Recomended Value & Model Evaluation \\
\hline Chi-Square & 58,953 & The smaller the better & \\
\hline Probabilitas & 0,003 & $\geq 0,05$ & Good Fit \\
\hline CMIN/DF & 1,842 & $\leq 2$ & Good Fit \\
\hline GFI & 0,912 & $\geq 0,90$ & Good Fit \\
\hline RMSEA & 0,086 & $\leq 0,08$ & Marginal Fit \\
\hline TLI & 0,969 & $\geq 0,95$ & Good Fit \\
\hline CFI & 0,912 & $\geq 0,95$ & Marginal Fit \\
\hline
\end{tabular}

Source: Authors' calculations.

The result of evaluation of Goodness of Fit Indices criteria in Table 1 shows that the evaluation of the overall model has been fulfilled, so the model can be accepted and can be interpreted for further discussion.

The results of hypothesis testing in Table 2 show that the resulting probability values for the three tested paths indicate that all variables have an error rate of $\leq 5 \%$. This means that the costumer orientation of service employee (COSE) has a significant 
effect on customer satisfaction and customer loyalty and customer satisfaction which significantly influence customer loyalty due to error rate $\leq 5 \%$ and value of C.R. more than 2. The results of the analysis proved that all hypotheses are tested based on the results of the analysis on hypothesis testing shown in Table 3.

Table 2. Test results of customer orientation of service employee (COSE) against customer loyalty and customer satisfaction

\begin{tabular}{|l|c|c|c|c|c|}
\hline \multicolumn{2}{|c|}{ Research Variabels } & $\begin{array}{c}\text { Koefisien } \\
\text { standardized (direct) }\end{array}$ & C.R. & Prob. \\
\hline COSE & $\rightarrow$ & CS & 0,428 & 4,656 & 0,000 \\
\hline COSE & $\rightarrow$ & CL & 0,321 & 3,236 & 0,001 \\
\hline CS & $\rightarrow$ & CL & 0,520 & 4,427 & 0,000 \\
\hline
\end{tabular}

Table 3. Test results of customer orientation of service employee (COSE) against customer loyalty through customer satisfaction

\begin{tabular}{|c|c|c|c|c|c|}
\hline \multirow{2}{*}{$\begin{array}{c}\text { Exogenous } \\
\text { Variables }\end{array}$} & \multirow{2}{*}{$\begin{array}{l}\text { Mediator } \\
\text { Variables }\end{array}$} & \multirow{2}{*}{$\begin{array}{c}\text { Endogenous } \\
\text { variables }\end{array}$} & \multicolumn{3}{|c|}{ Standard coefficients } \\
\hline & & & direct & indirect & Total \\
\hline COSE & $\begin{array}{c}\text { Customer } \\
\text { satisfaction (CS) }\end{array}$ & $\begin{array}{c}\text { Customer } \\
\text { Loyalty (CL) }\end{array}$ & 0,321 & $0,428 \times 0,520=0,222$ & 0,543 \\
\hline
\end{tabular}

Table 3 describes the result of the influencial analysis between research variables, both exogenous variables, to mediator and mediator variable to exogenous variables showing the value of standardized coefficient of direct, indirect and total influence. Based on Table 3, customer satisfaction is a mediation variable that can mediate the costumer orientation of service employee (COSE) to customer loyalty since the total value of influence is greater than the direct effect. The results of this analysis has proven the fourth tested hypothesis.

\section{Discussion}

Customer orientation of service employee (COSE) can influence patient satisfaction of type $\mathrm{C}$ of Private Hospitals in Surakarta, where patients will be satisfied if the health worker service is done by using patient needs approach. Patient satisfaction may increase if the service of health personnel is perceived to be good by the patient. The results of this study are in line with the research conducted by Cahyono (2012) which states that there is a significant influence between COSE and patient satisfaction. This is also supported by research conducted by Gustafsson et al. (2005) which states that customer orientation has a significant effect on customer satisfaction. Health workers who have the ability to make good decisions will be able to serve patients directly with good, able to perform actions to patients about the condition of the disease correctly so that patients feel safe and do not be afraid of the disease and foster a sense of satisfaction in the patient. The ability of the health worker technique is also a very important thing, where the correct technique can satisfy the patient's expectations. Technical skills such as in the case of nurses who measure blood pressure with a tension device and good communication skills by 
physicians making patients easily understand are important issues that get a good impression of the patient thereby increasing patient satisfaction.

The results of this study also indicate that there is an effect of COSE on patient loyalty in C type of Private hospitals in Surakarta. This suggests that the technical ability, social ability, motivating ability of the patient, and decision-making ability can increase patient loyalty. This result is in line with Hennig-Thurau (2004) study which states that COSE has a significant effect on loyalty. Based on the results of this study, health personnel who have the ability of engineering and decision-making ability can increase the loyalty of patients in discussing positive experiences related to the hospital. Easy-to-understand doctor's explanations and friendly nurses when measuring blood pressure with a tension tool can motivate the patient to talk positively about the hospital described by the patient's thank-you speech shortly after being examined by the doctor and served by the nurse. The accuracy of health workers in decision-making such as rapid handling of emergency patients needs help to make patients reluctant to talk positively about hospitals.

In terms of the relationship of customer satisfaction to customer loyalty, one of the keys to retaining customers is customer satisfaction. Satisfied customers will be loyal for longer periods of time, talking about good things about the company and its products to others, and not paying attention to competitor brands being less price sensitive (Kotler and Keller, 2011). Similarly, the results of this study indicate that there is a significant effect of patient satisfaction on patient loyalty. The results of this study are in line with the research of Chu et al. (2012) stating that high satisfaction or pleasure creates an emotional bond with the company so that it will affect customer loyalty.

\section{Conclusion}

The satisfaction of patients in private hospitals in Surakarta is able to mediate the influence of COSE on patient loyalty. Patients who are satisfied with hospital healthcare services will be loyal to the hospital. The technical ability and accuracy of the health worker in making decisions to the patient makes the patient have a good impression when receiving the service and will make the patient not reluctant to talk about the good things about the hospital. If the service provided is maintained then it will create an impression and experience continuously and finally the patient wants to always seek treatment in private hospitals in Surakarta although there are offers from other hospitals.

Patient satisfaction described by appropriate service expectations, the impression of receiving service, and experience during the service can improve patient loyalty in discussing good matters related to the hospital, recommending to others, and reusing hospital services. Patient satisfaction in this study is predominantly described by the impression of patients in receiving services as well as patients impressed with the hospitality and accuracy of handling health personnel in serving patients to make 
patients not hesitate to say good things related to services provided in the hospital. Patient's good greeting can certainly motivate patients to be more loyal to hospitals and voluntarily recommend hospitals to others.

\section{References:}

Ahearne, M., Bhattacharya, C.B. and Gruen, T. 2005. Antecedents and consequences of customer-company identification: Expanding the role of relationship marketing. Journal of applied psychology, 90(3), 574-587.

Andaleeb, S.S. 2001. Service quality perceptions and patient satisfaction: a study of hospitals in a developing country. Social science \& medicine, 52(9), 1359-1370.

Bowen, J.T. and Chen, S.L. 2001. The relationship between customer loyalty and customer satisfaction. International journal of contemporary hospitality management, 13(5), 213217.

Brady, M.K. and Cronin, Jr.J.J. 2001. Some new thoughts on conceptualizing perceived service quality: a hierarchical approach. Journal of marketing, 65(3), 34-49.

Cahyono, J. 2012. Factors Affecting Long-Term Cooperation to Increase Company Competitive Advantage. Journal of ASET Economics, 12(2).

Colwell, S., Hogarth-Scott, S., Jiang, D. and Joshi, A. 2009. Effects of organizational and serviceperson orientation on customer loyalty. Management Decision, 47(10), 1489-1513.

Cronin, Jr.J.J., Brady, M.K. and Hult, G.T.M. 2000. Assessing the effects of quality, value, and customer satisfaction on consumer behavioral intentions in service environments. Journal of retailing, 76(2), 193-218.

Dick, A.S. and Basu, K. 1994. Customer loyalty: toward an integrated conceptual framework. Journal of the academy of marketing science, 22(2), 99-113.

Ferdinand, A. 2000. Structural Equation Modeling in Management Research: Application of Models for Doctoral \& Doctoral Dissertation Thesis. Semarang: Undip BP.

Gustafsson, A., Johnson, M.D. and Roos, I. 2005. The effects of customer satisfaction, relationship commitment dimensions, and triggers on customer retention. Journal of marketing, 69(4), 210-218.

Hennig-Thurau, T. and Thurau, C. 2003. Customer orientation of service employeesToward a conceptual framework of a key relationship marketing construct. Journal of Relationship Marketing, 2(1-2), 23-41.

Hennig-Thurau, T. 2004. Customer orientation of service employees: Its impact on customer satisfaction, commitment, and retention. International journal of service industry management, 15(5), 460-478.

Hu, H.H., Kandampully, J. and Juwaheer, T.D. 2009. Relationships and impacts of service quality, perceived value, customer satisfaction, and image: an empirical study. The service industries journal, 29(2), 111-125.

Chu, P.Y., Lee, G.Y. and Chao, Y. 2012. Service quality, customer satisfaction, customer trust, and loyalty in an e-banking context. Social Behavior and Personality: an international journal, 40(8), 1271-1283.

Jarvis, L.P. and Wilcox, J.B. 1977. True vendor loyalty or simply repeat purchase behavior? Industrial Marketing Management, 6(1), 9-14.

Jayawardhena, C. and Farrell, A.M. 2011. Effects of retail employees' behaviours on customers' service evaluation. International Journal of Retail \& Distribution Management, 39(3), 203-217. 
Kelley, S.W. 1992. Developing customer orientation among service employees. Journal of the academy of Marketing Science, 20(1), 27-36.

Kotler, P. 2003. Marketing Management. Singapore: Prentice Hall.

Kotler, P. and Keller, K. 2011. Marketing management 14th edition. Prentice Hall.

Olsen, S.O. 2002. Comparative evaluation and the relationship between quality, satisfaction, and repurchase loyalty. Journal of the academy of marketing science, 30(3), 240-249.

Popli, S. and Rizvi, I.A. 2015. Exploring the relationship between service orientation, employee engagement and perceived leadership style: a study of managers in the private service sector organizations in India. Journal of Services Marketing, 29(1), 59-70.

Rangkuti, F. 2002. Measuring customer satisfaction: measuring techniques and strategies to improve customer quality. Jakarta: PT. Gramedia Main Library.

Roy, Dholakia, R. and Zhao, M. 2010. Effects of online store attributes on customer satisfaction and repurchase intentions. International Journal of Retail \& Distribution Management, 38(7), 482-496.

Trinastoro, L. 2005. Strategic Aspects of Hospital Management. Yogyakarta: Andi.

Wilson, A., Zeithaml, V.A., Bitner, M.J. and Gremler, D.D. 2012. Services marketing: Integrating customer focus across the firm, 2nd ed. McGraw Hill.

Wong, A. and Sohal, A. 2003. Service quality and customer loyalty perspectives on two levels of retail relationships. Journal of services marketing, 17(5), 495-513. 